Vol. 15 (2006): 324-339.

\title{
Performance, carcass quality, and gastric alterations in fattening pigs fed additives containing formic acid either coated with sorbate or mixed with lactic acid
}

\author{
Kirsi Partanen, Maija Karhapää, and Hilkka Siljander-Rasi \\ MTT Agrifood Research Finland, Animal Production Research, Pork and Poultry Production, \\ Tervamäentie 179, FI-05840 Hyvinkää, Finland, e-mail: kirsi.partanen@mtt.fi \\ Erkki Virtanen ${ }^{1}$ \\ Kemira GrowHow Ltd, Mechelininkatu 1a, PO Box 900, FI-00181 Helsinki, Finland \\ Bernt Nilsson \\ Kemira GrowHow Ltd, Industrigatan 70, PO Box 902, SE-251 09 Helsingborg, Sweden, \\ e-mail: bernt.nilsson@kemira-growhow.com
}

\begin{abstract}
The growth-promoting effects of two dietary acidifiers based on formic acid were studied with 320 fattening pigs from ca $21 \mathrm{~kg}$ to ca $105 \mathrm{~kg}$ of body weight. The sorbate-coated formic acid contained formic acid and ammonium formate which were absorbed in diatomaceous earth and coated with potassium sorbate. The investigated liquid blend contained formic and lactic acids as the major components. These acidifiers were added to grower and finisher diets at levels of 3, 6, and $12 \mathrm{~g} \mathrm{~kg}^{-1}$ of feed. The grower and finisher diets in the negative control treatment contained no growth promoters, but the grower diet in the positive control treatment was supplemented with avilamycin $\left(40 \mathrm{mg} \mathrm{kg}^{-1}\right)$. The investigated acidifiers did not influence the performance of growing pigs $(\mathrm{P}>0.05)$. In finishing pigs, all additions of the sorbate-coated formic acid improved daily weight gain compared to the negative control $(\mathrm{P}<0.05)$, whereas the feed conversion ratio was improved by additions of 3 and $12 \mathrm{~g} \mathrm{~kg}^{-1}$ of the acidifier. During the total fattening period, 6 and $12 \mathrm{~g}$ $\mathrm{kg}^{-1}$ of the sorbate-coated formic acid improved daily weight gain compared to the situation in the negative control $(\mathrm{P}<0.05)$, and $12 \mathrm{~g} \mathrm{~kg}^{-1}$ improved the feed conversion ratio $(\mathrm{P}<0.05)$. The addition of $3 \mathrm{~g} \mathrm{~kg}^{-1}$ of the blend of formic and lactic acids improved the daily weight gain of the finishing pigs and during the total fattening period, whereas the feed conversion ratio was improved by all the addition levels $(\mathrm{P}<0.05)$. The growth promoting effect of the two acidifiers did not differ significantly, and no significant linear or quadratic trends were found in the pigs' performance results between the addition levels from 3 to $12 \mathrm{~g} \mathrm{~kg}^{-1}$. The
\end{abstract}

1 Deceased. 
Vol. 15 (2006): 324-339.

\begin{abstract}
carcass quality of the pigs was not influenced by the acidifiers $(\mathrm{P}>0.05)$. The frequency of severe gastric alterations tended to be smaller when the diets contained $12 \mathrm{~g} \mathrm{~kg}^{-1}$ of the sorbate-coated formic acid $(\mathrm{P}=$ 0.07), but the results of the other acidifier treatments did not differ significantly from those in the negative control. In conclusion, both the sorbate-coated formic acid and the blend of formic and lactic acids have a growth-promoting effect in fattening pigs already in small dosages, but they do not influence carcass quality or cause gastric alterations.
\end{abstract}

Key words: fattening pigs, organic acids, performance, carcass quality, gastric ulcers

\section{Introduction}

Dietary formic acid additions have been shown to enhance the growth performance and/or feed conversion ratio of fattening pigs (Baustad 1993, Partanen et al. 2002). In those studies, dietary formic acid additions ranged from 5 to $12 \mathrm{~g} \mathrm{~kg}^{-1}$ of feed. Partanen et al. (2002) found that the growth-promoting effect of formic acid was improved when it was mixed with a small amount of potassium sorbate. In that study, grower and finisher diets contained $0.4 \mathrm{~g} \mathrm{~kg}^{-1}$ of potassium sorbate and $8 \mathrm{~g} \mathrm{~kg}^{-1}$ of formic acid. Although potassium sorbate is highly soluble in water (Sofos and Busta 1993), its solubility in formic acid is poor. Homogenous solutions of formic acid and potassium sorbate are difficult to achieve, because milky precipitation occurs already when potassium sorbate constitutes less than $5 \%$ of a mixture with formic acid. The problem of sorbate precipitation in formic acid could be overcome by absorbing formic acid first into a solid carrier such as diatomaceous earth and then coating it with potassium sorbate. When potassium sorbate solution is sprayed onto carrier containing formic acid, the sorbate is converted to sorbic acid forming a coating resistant to water and acidic environments (Swedish patent 0401672-1, Kemira GrowHow Ltd, Sweden).

Formic acid is corrosive and has a strong pungent odour, which makes it difficult to handle in feed mills. However, the corrosiveness and evaporation of formic acid have been reduced effectively by ammoniation of water-free formic acid or by absorbing formic acid into diatomaceous earth or by coating carrier-absorbed formic acid with sorb- ate (Virtanen et al. 2004). These make the handling of formic acid and its addition to feed easier and safer than the use of regular liquid formic acid. Absorbing formic acid into diatomaceous earth and coating it with sorbate has also enhanced the antimicrobial effect of formic acid against $E$. coli and Salmonella (Virtanen et al. 2004). So far, the growth-promoting effect of an acidifier, in which formic acid is absorbed in diatomaceous earth and coated with sorbate, has not been investigated with fattening pigs.

Dietary lactic acid additions have enhanced the growth performance of growing pigs (Jongbloed et al. 2000) and weaned piglets (Roth et al. 1993, Maribo 1999), but some studies have not been able to show significant performance improvement (Maribo et al. 2000a). Dietary lactic acid additions that have been able to enhance the growth performance of weaned piglets and growing pigs have usually been over $10 \mathrm{~g} \mathrm{~kg}^{-1}$ of feed, whereas generally less than $10 \mathrm{~g} \mathrm{~kg}^{-1}$ of formic acid is needed. The additions of combinations of lactic and formic acid, both at levels of 5 or $7 \mathrm{~g} \mathrm{~kg}^{-1}$ of feed have enhanced the performance of weaned piglets (Maribo et al. 2000b, Jørgensen and Boes 2004). Blends of formic acid and lactic acid (1:1 and 2:1) have also been reported to reduce the number of coliforms in the small intestine of piglets more effectively than plain formic acid (Franco et al. 2005). However, the growth-promoting effect of blends of formic acid and lactic acid has not been investigated with fattening pigs.

Dietary formate additions have enhanced the performance of pigs from weaning to slaughter when both piglet and fattening pig diets have been supplemented with formate (Kirchgessner et al. 
1997). Limiting dietary formate additions to the piglet period did not improve the performance of pigs from weaning to slaughter. However, the performance improvement produced by adding formate only to fattening diets equalled that produced by adding it to both piglet and fattening pig diets. According to Lindermayer and Propstmeier (1994), the advantage of dietary organic acid and in-feed antibiotic additions during the growing period is lost if these additives are removed from the finisher feed. The amount of feed consumed by fattening pigs from ca $25 \mathrm{~kg}$ to slaughter is large, generally over $220 \mathrm{~kg}$ per pig, and the majority of feed is consumed during the finishing period. To keep the cost of dietary organic acid additions at a reasonable level, it is necessary to find the minimum addition level at which the additive is effective during the whole fattening period. However, the growth-promoting effect of small dietary organic acid additions has scarcely been investigated in fattening pigs.

The aim of this experiment was to study the growth-promoting effect of two formic-acid-based acidifiers, when they were added to the diets of growing and finishing pigs at levels of 3, 6, and 12 $\mathrm{g} \mathrm{kg}^{-1}$ of feed. The sorbate-coated formic acid consisted of formic acid and ammonium formate that were absorbed in a diatomaceous earth carrier and coated with potassium sorbate. This product contained ca $50 \%$ diatomaceous earth. The investigated liquid blend contained formic and lactic acids as the major components. The acidifier-supplemented diets were compared to both negative and positive control treatments, in which the grower and finisher diets contained no growth promoters or the grower diet was supplemented with avilamycin, respectively. The effects of dietary acidifiers on the carcass quality of pigs and the presence of gastric alterations were also studied.

\section{Material and methods}

The experimental protocol was evaluated and approved by the Animal Care and Use Committee of MTT Agrifood Research Finland.

\section{Experimental procedures}

A total of 320 growing-finishing pigs (105 Finnish Landrace, 114 Yorkshire, and 101 crosses of these breeds) with an average initial body weight of 21.4 $\mathrm{kg}$ (SD 1.9) were used in the experiment. The pigs originated from the swine herd of MTT Agrifood Research Finland. Two gilts and two barrows were randomly allotted to pens of $1.7 \mathrm{~m} \times 2.5 \mathrm{~m}$, and the pens were randomly allotted to eight dietary treatments, 10 pens per treatment. To create low-hygiene growing conditions, faeces were removed from the pens only every second day. Manure was removed from the solid, concrete floor dunging areas daily by means of scrapers, which allowed diarrhoea to spread between the pens. Wood shavings were used as bedding material during the growing period only.

Two acidifiers based on formic acid were used. The sorbate-coated acidifier (BOLIFOR ${ }^{\circledR}$ Grower/ Finisher FA2300S, Kemira GrowHow Ltd, Sweden) consisted of formic acid and ammonium formate that were absorbed into a diatomaceous earth and coated with potassium sorbate. The ratio of sorbic to formic acid was 5.2:100, calculated as $100 \%$ acids. The investigated liquid blend (an experimental formula by Kemira GrowHow Ltd, Sweden) contained formic and lactic acids as the major components in a ratio of 28:100, calculated as $100 \%$ acids (in this paper it was named as the blend of formic and lactic acids). Both acidifiers were added to grower and finisher diets at levels of 3,6 , and $12 \mathrm{~g} \mathrm{~kg}^{-1}$ of feed. The basal grower and finisher diets without any growth promoters were used as a negative control treatment. In the positive control treatment, the grower diet was supplemented with avilamycin (40 mg kg ${ }^{-1}$; Maxus $\mathrm{G}^{\circledR}$, Elanco, Germany), whereas the finisher diet contained no growth promoters.

The experimental diets were based on barley, oats, and soybean meal, which were supplemented with pure amino acids, minerals, and vitamins (Table 1). The grower and finisher diets were formulated to meet the nutrient requirements of growing and finishing pigs according to Tuori et al. (1996). The grower and finisher diets contained 8.6 and 8.7 MJ of net energy ( $\mathrm{NE}$ ) calculated according to 
Vol. 15 (2006): 324-339.

Schiemann et al. (1972), 8.5 and $7.1 \mathrm{~g}$ of apparent ileal digestible lysine, 5.0 and $4.5 \mathrm{~g}$ of apparent ileal digestible methionine and cystine, 5.1 and 4.2 $\mathrm{g}$ of apparent ileal digestible threonine, 7.5 and 7.0 $\mathrm{g}$ of calcium, and 6 and $5.5 \mathrm{~g}$ of phosphorus per feed unit (feed unit $=9.3 \mathrm{MJ} \mathrm{NE}$ ), respectively. $\mathrm{Di}$ ets were pelleted at ca $60^{\circ} \mathrm{C}$ into 4 -mm pellets
(Amandus Kahl Nache, Germany). The pigs were fed according to a restricted, age-based feeding scale; growing pigs received 11.2-20.5 MJ NE per day for the first six weeks of the experiment and finishing pigs 22.3-29.8 MJ NE per day from week seven until slaughter. The daily feed allowance was given in two portions at 0700 and 1500 . Feed

Table 1. Ingredients of grower and finisher diets supplemented with avilamycin or increasing levels of a sorbate-coated formic acid or a blend of formic and lactic acids.

\begin{tabular}{|c|c|c|c|c|c|c|c|c|}
\hline \multirow[b]{2}{*}{ Acidifier addition, $\mathrm{g} \mathrm{kg}^{-1}$ of feed } & \multirow[t]{2}{*}{ Control } & \multirow[t]{2}{*}{$\begin{array}{l}\text { Avila- } \\
\text { mycin }\end{array}$} & \multicolumn{3}{|c|}{$\begin{array}{l}\text { Sorbate-coated } \\
\text { formic acid }\end{array}$} & \multicolumn{3}{|c|}{$\begin{array}{l}\text { Formic and lactic } \\
\text { acid blend }\end{array}$} \\
\hline & & & 3 & 6 & 12 & 3 & 6 & 12 \\
\hline \multicolumn{9}{|l|}{ Grower diets } \\
\hline Barley & 59.63 & 59.61 & 59.33 & 59.03 & 58.43 & 59.33 & 59.03 & 58.43 \\
\hline Oats & 20.00 & 20.00 & 20.00 & 20.00 & 20.00 & 20.00 & 20.00 & 20.00 \\
\hline Soybean meal & 17.64 & 17.64 & 17.64 & 17.64 & 17.64 & 17.64 & 17.64 & 17.64 \\
\hline Limestone & 0.72 & 0.72 & 0.72 & 0.72 & 0.72 & 0.72 & 0.72 & 0.72 \\
\hline Monocalcium phosphate & 0.57 & 0.57 & 0.57 & 0.57 & 0.57 & 0.57 & 0.57 & 0.57 \\
\hline Maxus $\mathrm{G}^{\circledR a}$ & - & 0.02 & - & - & - & - & - & - \\
\hline BOLIFOR® Grower/Finisher FA2300S ${ }^{b}$ & - & - & 0.30 & 0.60 & 1.20 & - & - & - \\
\hline Blend of formic and lactic acids ${ }^{c}$ & - & - & - & - & - & 0.30 & 0.60 & 1.20 \\
\hline Mineral-vitamin premix ${ }^{\mathrm{d}}$ & 1.30 & 1.30 & 1.30 & 1.30 & 1.30 & 1.30 & 1.30 & 1.30 \\
\hline L-Lysine $\mathrm{HCl}$ & 0.12 & 0.12 & 0.12 & 0.12 & 0.12 & 0.12 & 0.12 & 0.12 \\
\hline L-Threonine & 0.02 & 0.02 & 0.02 & 0.02 & 0.02 & 0.02 & 0.02 & 0.02 \\
\hline \multicolumn{9}{|l|}{ Finisher diets } \\
\hline Barley & 64.86 & 64.86 & 64.56 & 64.26 & 63.66 & 64.56 & 64.26 & 63.66 \\
\hline Oats & 20.00 & 20.00 & 20.00 & 20.00 & 20.00 & 20.00 & 20.00 & 20.00 \\
\hline Soybean meal & 12.60 & 12.60 & 12.60 & 12.60 & 12.60 & 12.60 & 12.60 & 12.60 \\
\hline Limestone & 0.69 & 0.69 & 0.69 & 0.69 & 0.69 & 0.69 & 0.69 & 0.69 \\
\hline Monocalcium phosphate & 0.45 & 0.45 & 0.45 & 0.45 & 0.45 & 0.45 & 0.45 & 0.45 \\
\hline BOLIFOR ${ }^{\circledR}$ Grower/Finisher FA2300S ${ }^{\mathrm{b}}$ & - & - & 0.30 & 0.60 & 1.20 & - & - & - \\
\hline Blend of formic and lactic acids ${ }^{c}$ & - & - & - & - & - & 0.30 & 0.60 & 1.20 \\
\hline Mineral-vitamin premix ${ }^{\mathrm{d}}$ & 1.30 & 1.30 & 1.30 & 1.30 & 1.30 & 1.30 & 1.30 & 1.30 \\
\hline L-Lysine $\mathrm{HCl}$ & 0.10 & 0.10 & 0.10 & 0.10 & 0.10 & 0.10 & 0.10 & 0.10 \\
\hline L-Threonine & 0.12 & 0.12 & 0.12 & 0.12 & 0.12 & 0.12 & 0.12 & 0.12 \\
\hline
\end{tabular}

${ }^{\text {a }}$ Maxus $\mathrm{G}^{\circledR}$ provided $40 \mathrm{mg}$ of avilamycin per $\mathrm{kg}$ of feed.

${ }^{\mathrm{b}}$ BOLIFOR ${ }^{\circledR}$ Grower/Finisher FA2300S contained formic acid and ammonium formate in a diatomaceous earth carrier and with a sorbate coating, and the ratio of sorbic to formic acid was 5.2:100, calculated as $100 \%$ acids.

${ }^{\mathrm{c}}$ The blend of formic and lactic acids contained formic and lactic acids as the major components in a ratio of 28:100 calculated as $100 \%$ acids.

${ }^{\mathrm{d}}$ Per kilogram of feed, the premix contained Ca, $2.3 \mathrm{~g} ; \mathrm{P}, 0.8 \mathrm{~g} ; \mathrm{Mg}, 0.5 \mathrm{~g}$; NaCl, $3.3 \mathrm{~g}, \mathrm{Fe}, 103 \mathrm{mg}$; Cu, $22 \mathrm{mg}$; Zn, 91 mg; Mn, $23 \mathrm{mg}$; Se, $0.28 \mathrm{mg}$; I, $0.28 \mathrm{mg}$; vitamin A, $5170 \mathrm{IU}$; vitamin $\mathrm{D}_{3}$, $517 \mathrm{IU}$; vitamin E, $50 \mathrm{mg}$; thiamin, $2 \mathrm{mg}$; riboflavin, $5 \mathrm{mg}$; pyridoxine, $3 \mathrm{mg}$; vitamin $\mathrm{B}_{12} 20 \mu \mathrm{g}$; biotin, $0.2 \mathrm{mg}$; pantothenic acid, $14 \mathrm{mg}$; niacin, $20 \mathrm{mg}$; folic acid, 2 $\mathrm{mg}$; and vitamin $\mathrm{K}, 2 \mathrm{mg}$. 


\section{Partanen, K. et al. Growth-promoting effects of two dietary acidifiers}

refusals were not measured, but the daily allowance was temporarily decreased if pigs did not finish their rations. Water was available ad libitum from drinking nipples, which were located in the dunging area.

For the first four weeks of the experiment, the pens were checked daily for the presence of diarrhoea. The consistency of faeces was scored as follows: $0=$ normal, solid faeces, $1=$ soft faeces, $2=$ moderate diarrhoea (soupy faeces), and $3=$ severe diarrhoea (watery faeces). The diarrhoea index was calculated as a sum of the daily diarrhoea scores during the observation period.

The pigs were weighed $0,3,6$, and 9 weeks from the beginning of the experiment and then weekly until they reached the weight of $103 \mathrm{~kg}$ and were slaughtered at a commercial slaughterhouse. Carcass lean percentage, fat thickness, and meat colour measurements were taken from hot carcasses with a Hennessy Grading Probe GP4 (Hennessy Grading Systems Ltd, Auckland, New Zealand). The measurements were taken in two locations: the first one after the last rib, $8 \mathrm{~cm}$ from the midline, and the second one between the 12th and 13th rib, $6 \mathrm{~cm}$ from the midline.

The stomachs of 206 randomly selected pigs were collected at slaughter to investigate the pres- ence of gastric alterations. At the abattoir, the stomachs were opened, emptied, rinsed, and chilled to a temperature close to $0^{\circ} \mathrm{C}$. The stomachs were transported to the laboratory, and they were visually evaluated on the day after the slaughter for abnormalities in the pars oesophageal region using the scoring scale adopted from Hautala and Rautiainen (1991) and described in Table 2. The presence of different types of alterations (keratinisation, streaky grooves or tiny erosions, erosion down to muscular part, scarring, and stenosis) seen in the first-, second-, and third-grade lesions were recorded too. The second- and third-grade lesions and stenosis of the oesophageal opening were considered to cause discomfort and influence the welfare of the pig (Hautala and Rautiainen 1991).

\section{Chemical analyses}

The experimental feeds were prepared in $1000-\mathrm{kg}$ batches, and each batch was sampled and analysed for $\mathrm{pH}$. The $\mathrm{pH}$ was measured from a feed-water mixture (50 g feed per $100 \mathrm{ml}$ water) which had been stirred with a whirl mixer for $20 \mathrm{sec}$ and kept at room temperature for $15 \mathrm{~min}$ and then remixed. During the experiment, the feeds were sampled

Table 2. Scoring scale for the evaluation of gastric lesions in the pars oesophageal region of the pigs' stomach (Hautala and Rautiainen 1991).

\begin{tabular}{llc}
\hline Score & Description & $\begin{array}{c}\text { Influences the } \\
\text { welfare of the pig }\end{array}$ \\
\hline 0 & $\begin{array}{l}\text { A well demarcated white, yellow, or grey squamous epithelium over the pars oesophageal } \\
\text { area. The surface undulates slightly. }\end{array}$ & No \\
& $\begin{array}{l}\text { Hyperkeratinisation (roughness and flaky scales) in the oesophageal region of the stomach } \\
\text { that is usually discoloured yellow (bile staining) and/or pitted (seen as streaky grooves or } \\
\text { dark spotty holes) or minutely eroded and/or covered with mature scarring without } \\
\text { stenosis of the oesophageal opening. }\end{array}$ & No \\
& $\begin{array}{l}\text { Ulceration, i.e. erosion down to the muscular part of the mucosa for less than 50\% of the } \\
\text { pars oesophageal area. }\end{array}$ & Yes \\
& $\begin{array}{l}\text { Ulceration for } 50 \% \text { or more of the pars oesophageal area and/or haemorrhagic ulceration } \\
\text { and/or occurrence of a perforated ulcer and/or the wall of the stomach has clearly } \\
\text { thickened and there is an inflammation of the serosa around the lesion. }\end{array}$ & Yes \\
& $\begin{array}{l}\text { Scarring has narrowed the opening of the oesophagus. The stenosis feels like a rigid ring } \\
\text { when one or two fingers are pushed into the opening of the oesophagus. }\end{array}$ & Yes \\
Stenosis &
\end{tabular}


Vol. 15 (2006): 324-339.

once a month and analysed for dry matter by drying at $103^{\circ} \mathrm{C}$ for $16 \mathrm{~h}$. At the end of the experiment, the sub-samples of each 1000-kg feed batch were pooled and analysed for ash, nitrogen, amino acids, and buffering capacity. Ash was determined according to the method 942.05 of the Association of Official Analytical Chemists (1990). Nitrogen was determined according to the Dumas method using a Leco $\mathrm{N}$ analyser, and crude protein content was calculated as $6.25 \times \mathrm{N}$. Amino acids were analysed according to the official EU method (EC 1998). Buffering capacity at a $\mathrm{pH}$ of 3.0 and 4.0 was determined according to Prohászka and Baron (1980).

\section{Statistical analyses}

The pigs were group-fed in pens of four animals, and therefore the pen was considered as the experimental unit. The performance data were analysed with the MIXED procedure of SAS (SAS® for Windows, version 8.2) using the following model (Snedecor and Cochran 1989):

$$
\mathrm{Y}_{\mathrm{ij}}=\mu+t_{\mathrm{i}}+\varepsilon_{\mathrm{ij}}
$$

where $t_{\mathrm{i}}$ is the fixed effect of treatment $i(i=1, \ldots 8)$, and $\varepsilon_{\mathrm{ij}}$ is the normally distributed error with mean 0 and variance $\sigma^{2}$. Organic acid treatments were compared to the negative and positive control treatments by the Dunnett test. The two acidifiers were compared to each other by contrasting the levels $3-12 \mathrm{~g} \mathrm{~kg}^{-1}$ of the sorbate-coated formic acid with the levels $3-12 \mathrm{~g} \mathrm{~kg}^{-1}$ of the blend of formic and lactic acids. The effect of dietary acidifier level (3, 6, and $12 \mathrm{~g} \mathrm{~kg}^{-1}$ feed) was investigated separately for both acidifiers by using orthogonal polynomials (linear and quadratic effect). Residuals were checked for normality. Frequencies of gastric alterations caused by erosion of the pars oesophageal area (erosion down to muscular part, scarring, and stenosis) and severe gastric lesions (grades 2 and 3) believed to cause discomfort to the pigs were analysed with the CATMOD procedure of SAS to determine the effect of treatment. The additive treatments were compared to the negative control treatment using the CONTRAST statement.

\section{Results and discussion}

\section{Diet composition}

The analysed chemical composition of grower and finisher diets is presented in Table 3. The analysed crude protein contents were similar among the grower and finisher diets, but there were slight differences in the analysed amino acid contents. Because the experimental feeds were manufactured in $1000-\mathrm{kg}$ batches as the experiment proceeded, the differences in the analysed amino acid contents probably reflect variations in the amino acid contents of the major feed ingredients, cereals and soybean meal. Sorbate-coated formic acid additions of 3-12 $\mathrm{g} \mathrm{kg}^{-1}$ of feed reduced the $\mathrm{pH}$ of the grower feed by $0.20-0.56 \mathrm{pH}$ units and that of the finisher feed by $0.23-0.67 \mathrm{pH}$ units. Additions of formic and lactic acid blend reduced the dietary pH slightly more: by $0.34-0.90 \mathrm{pH}$ units in the grower feed and by $0.41-1.05 \mathrm{pH}$ units in the finisher diet. The finding that the blend of formic and lactic acids had a greater effect on dietary $\mathrm{pH}$ than the sorbate-coated formic acid was expected, as the latter contained ca 50\% carrier, and it was calculated to provide only $1.3,2.6$, and $5.2 \mathrm{~g}$ of $100 \%$ formic acid per $\mathrm{kg}$ of feed. Sorbic acid additions were very small $-0.07,0.14$, and $0.29 \mathrm{~g} \mathrm{~kg}^{-1}$ of feed - and sorbic acid has generally little influence on dietary $\mathrm{pH}$ (Kirchgessner et al. 1995). The blend of formic and lactic acids provided 2.6, 5.2, and $10.4 \mathrm{~g} \mathrm{100- \%}$ acid per $\mathrm{kg}$ of feed, and the ratio of lactic to formic acid was 28:100. The grower feed contained more soybean meal and mineral supplements and less barley than the finisher feed. Both protein and mineral sources have a higher ability to resist $\mathrm{pH}$ change through acid addition than cereals do (Giger-Reverdin et al. 2002), which explains the observed smaller reduction in dietary $\mathrm{pH}$ in the grower than in the finisher feeds supplemented with acidifiers. Dietary acidifiers did not 
Partanen, K. et al. Growth-promoting effects of two dietary acidifiers

Table 3. Analysed nutrient composition of grower and finisher diets supplemented with avilamycin or increasing levels of a sorbate-coated formic acid or a blend of formic and lactic acids.

\begin{tabular}{|c|c|c|c|c|c|c|c|c|}
\hline \multirow[b]{2}{*}{ Acidifier addition, $\mathrm{g} \mathrm{kg}^{-1}$ of feed } & \multirow[t]{2}{*}{ Control } & \multirow[t]{2}{*}{ Avilamycin } & \multicolumn{3}{|c|}{$\begin{array}{l}\text { Sorbate-coated } \\
\text { formic acid }\end{array}$} & \multicolumn{3}{|c|}{$\begin{array}{l}\text { Formic and lactic } \\
\text { acid blend }\end{array}$} \\
\hline & & & 3 & 6 & 12 & 3 & 6 & 12 \\
\hline \multicolumn{9}{|l|}{ Grower diets } \\
\hline Dry matter, $\%$ & 87.7 & 87.7 & 87.6 & 87.8 & 87.9 & 88.1 & 88.9 & 87.8 \\
\hline Ash, $\mathrm{g} \mathrm{kg}^{-1}$ dry matter & 59 & 60 & 62 & 61 & 63 & 60 & 57 & 57 \\
\hline Crude protein, $\mathrm{g} \mathrm{kg}^{-1}$ dry matter & 189 & 193 & 193 & 190 & 189 & 193 & 193 & 195 \\
\hline \multicolumn{9}{|l|}{ Amino acids, $\mathrm{g} \mathrm{kg}^{-1}$ dry matter } \\
\hline Lysine & 10.0 & 10.3 & 10.9 & 10.0 & 10.1 & 10.5 & 9.5 & 10.4 \\
\hline Methionine & 2.8 & 3.0 & 3.0 & 2.8 & 2.7 & 2.8 & 2.5 & 2.8 \\
\hline Cystine & 3.4 & 3.7 & 3.8 & 3.3 & 3.5 & 3.3 & 3.0 & 3.6 \\
\hline Threonine & 6.9 & 7.5 & 7.7 & 7.3 & 6.9 & 7.1 & 6.6 & 6.8 \\
\hline $\mathrm{pH}$ & 5.61 & 5.60 & 5.41 & 5.35 & 5.05 & 5.27 & 5.09 & 4.71 \\
\hline \multicolumn{9}{|c|}{ Buffering capacity, meq $\mathrm{kg}^{-1}$ dry matter } \\
\hline $\mathrm{pH} 4$ & 516 & 547 & 571 & 501 & 562 & 520 & 489 & 444 \\
\hline $\mathrm{pH} 3$ & 657 & 661 & 731 & 676 & 751 & 690 & 671 & 684 \\
\hline \multicolumn{9}{|l|}{ Finisher diets } \\
\hline Dry matter, $\%$ & 88.2 & 88.2 & 88.0 & 88.1 & 88.0 & 88.1 & 88.0 & 87.7 \\
\hline Ash, $\mathrm{g} \mathrm{kg}^{-1}$ dry matter & 57 & 57 & 59 & 60 & 62 & 58 & 58 & 57 \\
\hline Crude protein, $\mathrm{g} \mathrm{kg}^{-1}$ dry matter & 173 & 173 & 174 & 175 & 174 & 177 & 176 & 176 \\
\hline \multicolumn{9}{|l|}{ Amino acids, $\mathrm{g} \mathrm{kg}^{-1}$ dry matter } \\
\hline Lysine & 9.2 & 9.2 & 9.0 & 8.8 & 8.6 & 9.2 & 9.4 & 8.5 \\
\hline Methionine & 2.8 & 2.8 & 2.8 & 2.6 & 2.7 & 2.8 & 2.6 & 2.7 \\
\hline Cystine & 3.5 & 3.5 & 3.7 & 3.5 & 3.6 & 3.5 & 3.5 & 3.7 \\
\hline Threonine & 6.2 & 6.2 & 6.7 & 6.4 & 6.2 & 6.9 & 6.8 & 6.5 \\
\hline $\mathrm{pH}$ & 5.72 & 5.72 & 5.49 & 5.31 & 5.05 & 5.27 & 5.09 & 4.71 \\
\hline \multicolumn{9}{|c|}{ Buffering capacity, meq $\mathrm{kg}^{-1}$ dry matter } \\
\hline $\mathrm{pH} 4$ & 524 & 524 & 557 & 620 & 423 & 477 & 409 & 394 \\
\hline pH 3 & 655 & 655 & 680 & 745 & 593 & 626 & 584 & 616 \\
\hline
\end{tabular}

have any profound or consistent effect on the dietary buffering capacity of the grower and finisher feeds, which is in accordance with our previous results (Partanen et al. 2002).

\section{Health of pigs}

In general, the health status of the pigs was good, and they completed the trial successfully, except for seven pigs which were removed from the experiment. Three pigs died suddenly (one pig each in the negative control treatment and treatments with sorbate-coated formic acid and the blend of formic and lactic acids) during the trial, one pig was removed from the trial because of an infection on the head (in the negative control treatment), and three pigs were removed from the trial because of lameness (one pig in the positive control treatment and two in the treatments with sorbate-coated formic acid). The average removal rate was $2.2 \%$. In the negative control treatment, two pigs in the same pen were medicated because their tails had been bitten. 
Vol. 15 (2006): 324-339.

In general, the presence of diarrhoea was low during the first four weeks of the experiment (Table 4). No cases of severe diarrhoea (score 3) were observed, whereas moderate diarrhoea (score 2) was seen in 11 pens for 1-2 days. Soft faeces (score 1) were recorded more often but only occasionally and not for longer than four consecutive days. The number of diarrhoea days and the diarrhoea index per pen were low, and they were not influenced by dietary additions of sorbate-coated formic acid $(\mathrm{P}>0.05)$. The additions of the blend of formic and lactic acids linearly decreased $(\mathrm{P}<$ $0.05)$ the number of diarrhoea days and the diarrhoea index, but none of the treatments with different levels of this blend differed significantly from the control treatment $(\mathrm{P}>0.05)$. The pigs of this study came from one herd, and they were moved only a short distance from the weaner to the fattening units. The purpose of starting the experiment at a body weight of ca $20 \mathrm{~kg}$ and reducing the cleaning frequency of the pens was to increase the risk of diarrhoea in this study. Despite these actions, the frequency of diarrhoea was low. In other organic acid studies with fattening pigs, no or little diarrhoea has been observed too (Baustad 1993, $\varnothing$ verland et al. 2000). Transportation and mixing of piglets from different environmental backgrounds generally increase the incidence of diar- rhoea in growing pigs and reduce growth performance (Biehl et al. 1985). In the study of Partanen et al. (2002), pigs from ten different farms were transported and mixed for fattening, and the incidence of diarrhoea was greater than in this study. Partanen et al. (2002) observed that additions of formic acid and additions of formic acid and sorbate both effectively reduced the incidence of diarrhoea in pigs fed a diet of barley and soybean meal but not in pigs fed a high-fibre diet. In pigs fed a high-fibre diet, the frequency of diarrhoea was generally low.

\section{Growth performance and feed utilisation}

The pigs consumed their feed readily; feed refusals were only occasionally found. During the 40day growing period, the additions of the sorbatecoated formic acid did not have any significant influence on the weight gain or feed conversion ratio of the pigs $(\mathrm{P}>0.05)$, but the daily weight gain was numerically the lowest in the control treatment and up to $60 \mathrm{~g} \mathrm{~d}^{-1}$ higher in the treatment with $6 \mathrm{~kg}^{-1}$ of the sorbate-coated formic acid (Table 5). In finishing pigs, however, all addition levels resulted in higher daily weight gain $(\mathrm{P}<0.05)$, and the addition levels of 3 and $12 \mathrm{~g} \mathrm{~kg}^{-1}$ improved

Table 4. The incidence of diarrhoea in growing pigs fed diets supplemented with avilamycin or increasing levels of a sorbate-coated formic acid or a blend of formic and lactic acids.

\begin{tabular}{|c|c|c|c|c|c|c|c|c|c|}
\hline \multirow[b]{2}{*}{ Acidifier addition, $\mathrm{g} \mathrm{kg}^{-1}$ of feed } & \multirow[t]{2}{*}{ Control } & \multirow[t]{2}{*}{ Avilamycin } & \multicolumn{3}{|c|}{$\begin{array}{l}\text { Sorbate-coated formic } \\
\text { acid }\end{array}$} & \multicolumn{3}{|c|}{$\begin{array}{c}\text { Formic and lactic acid } \\
\text { blend }\end{array}$} & \multirow[b]{2}{*}{ SEM } \\
\hline & & & 3 & 6 & 12 & 3 & 6 & 12 & \\
\hline \multicolumn{10}{|l|}{ Frequencies of pens with ${ }^{\text {a }}$} \\
\hline Normal faeces & 0.5 & 0.6 & 0.4 & 0.6 & 0.5 & 0.3 & 0.2 & 0.5 & \\
\hline Soft faeces & 0.4 & 0.4 & 0.5 & 0.2 & 0.3 & 0.6 & 0.6 & 0.3 & \\
\hline Moderate diarrhoea & 0.1 & 0.0 & 0.1 & 0.2 & 0.2 & 0.1 & 0.2 & 0.2 & \\
\hline Diarrhoea days ${ }^{\mathrm{c}}$ & 1.1 & 1.3 & 2.1 & 1.4 & 1.4 & 2.7 & 3.1 & 0.5 & 0.74 \\
\hline Diarrhoea index $\mathrm{x}^{\mathrm{b}, \mathrm{c}}$ & 1.3 & 1.3 & 2.3 & 1.6 & 1.6 & 2.9 & 3.5 & 0.7 & 0.86 \\
\hline
\end{tabular}

${ }^{a}$ In pens with normal faeces, all the daily faecal scores were 0 during the whole observation period. In pens with soft faeces, daily faecal scores ranged from 0 to 1 , and scores in pens with moderate faeces ranged from 0 to 2 .

${ }^{\mathrm{b}}$ Diarrhoea index = a sum of daily diarrhoea scores during the first 26 days of the experiment.

${ }^{c}$ The effect of the addition level of the acidifier containing formic acid and lactic acid was linear $(\mathrm{P}<0.05)$. 


\section{Partanen, K. et al. Growth-promoting effects of two dietary acidifiers}

the feed conversion ratio compared to the value in the negative control $(\mathrm{P}<0.05)$. During the total fattening, the addition levels of 6 and $12 \mathrm{~g} \mathrm{~kg}^{-1}$ improved the daily weight gain compared to value in the negative control $(\mathrm{P}<0.05)$, and the highest addition level reduced the total amount of feed consumed per pig and improved the feed conversion ratio compared to the negative control's values $(\mathrm{P}<0.05)$. However, there were no significant differences in the daily feed consumption. The feed conversion ratio was better than in the positive control treatment $(\mathrm{P}<0.05)$. These pigs reached the targeted end weight of $110 \mathrm{~kg}$ sooner than those of the negative control $(\mathrm{P}<0.05)$ when the diets were supplemented with $6 \mathrm{~g} \mathrm{~kg}^{-1}$ of the sorbate-coated formic acid. The addition levels of 6 and $12 \mathrm{~g} \mathrm{~kg}^{-1}$ of the sorbate-coated formic acid increased carcass gain compared to the negative control's value $(\mathrm{P}<0.05)$ and the amount of dry matter consumed per $\mathrm{kg}$ of carcass gain was lower when the highest addition level was used. Carcass gain was calculated by calculating $26.1 \%$ of slaughter loss for a $21-\mathrm{kg}$ pig. No clear linear or quadratic trend in the performance results of the pigs was seen among the acidifier levels of 3 to 12 $\mathrm{g} \mathrm{kg}^{-1}(\mathrm{P}>0.05)$.

Table 5. Growth performance and feed utilisation of growing-finishing pigs fed diets supplemented with avilamycin or increasing levels of a sorbate-coated formic acid or a blend of formic and lactic acids.

\begin{tabular}{|c|c|c|c|c|c|c|c|c|c|}
\hline \multirow[b]{2}{*}{ Acidifier addition, $\mathrm{g} \mathrm{kg}^{-1}$ of feed } & \multirow[t]{2}{*}{ Control } & \multirow[t]{2}{*}{$\begin{array}{l}\text { Avila- } \\
\text { mycin }\end{array}$} & \multicolumn{3}{|c|}{$\begin{array}{l}\text { Sorbate-coated } \\
\text { formic acid }\end{array}$} & \multicolumn{3}{|c|}{$\begin{array}{l}\text { Formic and lactic } \\
\text { acid blend }\end{array}$} & \multirow[b]{2}{*}{ SEM } \\
\hline & & & 3 & 6 & 12 & 3 & 6 & 12 & \\
\hline Pens & 10 & 10 & 10 & 10 & 10 & 10 & 10 & 10 & \\
\hline Pigs & 38 & 39 & 39 & 39 & 39 & 39 & 40 & 40 & \\
\hline \multicolumn{10}{|l|}{ Weight, $\mathrm{kg}$} \\
\hline Initial & 21.3 & 21.4 & 21.4 & 21.8 & 20.9 & 21.3 & 21.2 & 21.8 & 0.53 \\
\hline End of grower period & 51.6 & 53.8 & 52.6 & 54.5 & 51.3 & 53.2 & 52.9 & 54.1 & 1.24 \\
\hline Final & 104.6 & 105.8 & 105.0 & 105.0 & 105.6 & 105.4 & 105.3 & 104.7 & 0.61 \\
\hline Days in trial & 96.5 & 93.4 & 92.6 & $90.3^{\S}$ & 92.8 & $91.2^{\S}$ & 93.2 & $91.1^{\S}$ & 1.87 \\
\hline \multicolumn{10}{|l|}{ Weight gain, $\mathrm{g} \mathrm{d}^{-1}$} \\
\hline Grower period & 758 & 810 & 781 & 818 & 761 & 799 & 793 & 808 & 25.4 \\
\hline Finisher period & 957 & 987 & $1019^{\S}$ & $1017^{\S}$ & $1043^{\S}$ & $1031^{\S}$ & 1005 & 1008 & 21.0 \\
\hline Total fattening & 872 & 911 & 915 & $928^{\S}$ & $921^{\S}$ & $928^{\S}$ & 912 & 919 & 17.1 \\
\hline \multicolumn{10}{|c|}{ Feed consumption, $\mathrm{kg}$ of dry matter day ${ }^{-1}$} \\
\hline Grower period & 1.52 & 1.56 & 1.56 & 1.60 & 1.51 & 1.57 & 1.55 & 1.58 & 0.031 \\
\hline Finisher period & 2.61 & 2.72 & 2.66 & 2.74 & 2.61 & 2.69 & 2.65 & 2.65 & 0.042 \\
\hline Total fattening & 2.16 & 2.22 & 2.18 & 2.23 & 2.13 & 2.20 & 2.17 & 2.17 & 0.028 \\
\hline \multicolumn{10}{|c|}{ Feed consumption, $\mathrm{kg}$ of dry matter pig $^{-1}$} \\
\hline Grower period & 60.7 & 62.3 & 62.4 & 63.8 & 60.3 & 62.6 & 61.8 & 63.1 & 1.23 \\
\hline Finisher period & 148.8 & 145.1 & 139.8 & 137.8 & 137.7 & 137.5 & 139.5 & $134.6^{\S}$ & 4.02 \\
\hline Total fattening & 209.5 & 207.4 & 202.2 & 201.6 & $198.0^{\S}$ & 200.2 & 201.4 & $197.7^{\S}$ & 3.56 \\
\hline \multicolumn{10}{|c|}{ Feed conversion ratio, $\mathrm{kg}$ of dry matter per $\mathrm{kg}$ of gain } \\
\hline Grower period & 2.01 & 1.93 & 2.01 & 1.96 & 1.99 & 1.96 & 1.96 & 1.96 & 0.037 \\
\hline Finisher period & 2.82 & 2.79 & $2.66^{\S}$ & 2.73 & $2.53^{\S \pi}$ & $2.63^{\S \pi}$ & $2.67 \S$ & $2.67^{\S}$ & 0.050 \\
\hline Total fattening & 2.51 & 2.46 & 2.42 & 2.42 & $2.34^{\S \pi}$ & $2.38^{\S}$ & $2.40^{\S}$ & $2.39^{\S}$ & 0.037 \\
\hline
\end{tabular}

$\S$ Significantly different from the control treatment according to the Dunnett test $(\mathrm{P}<0.05)$.

"Significantly different from the avilamycin treatment according to the Dunnett test $(\mathrm{P}<0.05)$. 
Vol. 15 (2006): 324-339.

In the study of Sigfridson and Göransson (2003) with fattening pigs weighing $27-115 \mathrm{~kg}$, the same sorbate-coated formic acid as in this study was used at levels of 3 and $6 \mathrm{~g} \mathrm{~kg}^{-1}$ of feed. Contrary to our findings, they reported that 3 and 6 $\mathrm{g} \mathrm{kg}^{-1}$ of sorbate-coated formic acid enhanced the weight gain of growing pigs, but only the addition of $3 \mathrm{~g} \mathrm{~kg}^{-1}$ improved the feed conversion ratio compared to the negative control treatment's value. However, the weight gain and feed conversion ratio of finishing pigs were not affected by dietary acid additions in that experiment. During total fattening, only the addition of $3 \mathrm{~g} \mathrm{~kg}^{-1}$ resulted in improvements in weight gain and feed conversion ratio compared to the control's values. In that study, pigs were fed the same feed based on wheat, barley, soybean meal, and rapeseed meal throughout both the growing and finishing periods, and this feed had lower amino acid contents than the diets of this study. In the study of Maribo et al. (2004) with piglets aged 4-10 weeks, an acidifier containing formic, phosphoric, lactic and citric acids, and sodium formate in a diatomaceous earth carrier did not have any significant effect on the growth performance of weaned piglets at dietary addition levels of 3-9 $\mathrm{g} \mathrm{kg}^{-1}$ of feed. However, adding $6 \mathrm{~g} \mathrm{~kg}^{-1}$ of feed of an acidifier containing formic, phosphoric and citric acids and ammonium and sodium formate in a diatomaceous earth carrier and with a sorbate coating improved weight gain from 535 to $570 \mathrm{~g} \mathrm{~d}^{-1}$ and slightly decreased the feed conversion ratio.

Because the sorbate-coated formic acid contained ca 50\% diatomaceous earth, the effective acid additions were small. It is unclear why such small acid additions were effective growth promoters in fattening pigs. Diatomaceous earth consists of fossilised skeletons of diatoms and other algae and has porous particles with a high capacity to absorb liquids. It also has toxin binding properties (Korunic 1998). Dietary diatomaceous earth additions have increased faecal dry matter content and decreased nitrogen excretion in the faeces and urine of weaned piglets (Bolduan et al. 1991). It is not known in what part of the digestive tract, how fast, and to what extent formic acid is released from the diatomaceous earth. According to Vir- tanen et al. (2004), the use of diatomaceous earth enhances the antimicrobial effect of formic acid, which could explain the growth-promoting effect of small dietary levels of a sorbate-coated formic acid.

The sorbate coating may also have played a role in enhancing the growth-promoting effect of the carrier-absorbed formic acid. A sorbate-coated acidifier has enhanced the growth performance of weaned piglets at a dietary level of $6 \mathrm{~g} \mathrm{~kg}^{-1}$ of feed, whereas the same amount of a similar acidifier without a sorbate coating has not (Maribo et al. 2004). Dietary sorbic acid additions have been reported to result in substantial growth-promoting effects in weaned piglets (Kirchgessner et al. 1995, Roth and Raczek 2003). Sorbates are known to have an antimicrobial effect in relatively small dosages when the $\mathrm{pH}$ is lowered by other acids (Sofos and Busta 1993). This could explain the synergistic growth-promoting effect of small sorbate additions in combination with formic acid (Partanen et al. 2002). The pKa value of sorbic acid is 4.76 , and it displays inhibitory activity primarily against yeasts and moulds; the activity against bacteria is not as comprehensive and appears to be selective (Sofos and Busta 1993, Matsuda et al. 1994). Sorbates have the advantage of being effective at $\mathrm{pH}$ values as high as 6.5-7.0, whereas most other organic acids require a lower pH to be effective (Sofos and Busta 1993, Matsuda et al. 1994).

The blend of formic and lactic acids did not influence the weight gain or feed conversion ratio of growing pigs $(\mathrm{P}>0.05)$. In the finishing period and during total fattening, only the smallest addition level resulted in a higher daily weight gain than in the negative control treatment $(\mathrm{P}<0.05)$. However, all the addition levels resulted in better feed conversion ratios than in the negative control treatment $(\mathrm{P}<0.05)$. The addition levels of 3 and $12 \mathrm{~g} \mathrm{~kg}^{-1}$ increased carcass gain $(\mathrm{P}<0.05)$, and all addition levels decreased $(\mathrm{P}<0.05)$ the amount of dry matter consumed per $\mathrm{kg}$ of carcass gain compared to the negative control's values. No clear linear or quadratic trend in the performance results of pigs was seen among the acidifier levels of 3 to 12 $\mathrm{g} \mathrm{kg}^{-1}(\mathrm{P}>0.05)$. Blends containing formic acid 
and lactic acid have not been studied in fattening pigs. In 4- to 10-wk-old weaned piglets, dietary additions of $7 \mathrm{~g} \mathrm{~kg}^{-1}$ of both formic and lactic acid improved weight gain by $10 \%$ (Maribo et al. $2000 \mathrm{~b}$ ). A smaller addition of $5 \mathrm{~g} \mathrm{~kg}^{-1}$ of both formic and lactic acid enhanced weight gain by $4 \%$ in piglets weighing 9-32 kg (Jørgensen and Boes 2004).

There were no significant differences between the studied formic-acid-based acidifiers in the performance results and carcass quality of fattening pigs. However, both studied acidifiers enhanced the performance of finishing pigs but not that of growing pigs. This is in accordance with our previous results (Partanen et al. 2002). Contrary results have been reported in several studies (Kirchgessner et al. 1997, Siljander-Rasi et al. 1998, Øverland et al. 2000, Sigfridson and Göransson 2003), in which growing pigs have benefited from dietary acidification whereas finishing pigs have not. In this study, the variation in the growth rate of pigs was larger among the growing than the finishing pigs (coefficients of variation were 15.6 and $12.5 \%$, respectively). This larger variation could be one reason for the lack of a significant acid effect during the growing period, for the average growth rates of growing pigs fed acidifier-supplemented diets were up to $8 \%$ greater than in the negative control treatment.

Several modes of action of dietary organic acid additions have been proposed (Partanen and Mroz 1999). It seems that they influence the microflora of pigs, which reduces nutrient loss to bacteria and yeast (Jensen 1998, Maribo et al. 2000a, b). Jensen (1998) has calculated that the amount of energy saved for the animals by the reduced microbial fermentation almost equals the improved feed to gain ratio. Several studies have shown that dietary organic acid additions improve the apparent ileal digestibility of essential amino acids in fattening pigs (Partanen and Mroz 1999), and dietary formic acid additions have been shown to improve the digestibility of fat too (Partanen et al. 2001). Improved apparent amino acid digestibility results from the reduced flow of bacterial nitrogen in the ileum (Partanen et al. 2001), which supports the hypothesis of reducing nutrient loss to microbes.
There were, however, some differences in the analysed total amino acid contents of the experimental feeds, which may have had some influence on the growth performance and feed utilisation of the pigs (Ferguson et al. 2001). Because the thickness of fat and the carcass lean percentage were similar among the experimental treatments, it is relevant to assume that the differences in the apparent ileal amino acid supply between the experimental treatments were however fairly small.

The use of avilamycin in the grower diet did not enhance the performance of the pigs during the growing period or the whole fattening period when compared to the negative control $(\mathrm{P}>0.05)$. In general, avilamycin and other antibiotic growth promoters have enhanced the performance of growing pigs. However, the use of antibiotic growth promoters only in grower feed has not resulted in improved performance results during the whole fattening period (Lindermayer and Propstmeier 1994, Siljander-Rasi et al. 1998, Partanen et al. 2002). The growth performance and feed conversion ratios of growing pigs fed diets supplemented with organic acids did not differ from those fed grower feed with avilamycin $(\mathrm{P}>0.05)$. During the total fattening period, only the largest addition of sorbate-coated formic acid resulted in better feed conversion than in the positive control treatment $(\mathrm{P}<0.05)$.

\section{Carcass quality}

Neither the sorbate-coated formic acid nor the formic and lactic acid blend had any significant influence on carcass leanness, fat thickness, or meat colour measurement compared to the values in the negative and positive control treatments (Table 6). This is in accordance with previous studies (Siljander-Rasi et al. 1998, Partanen et al. 2002, Sigfridson and Göransson 2003). According to the review of Royer and Granier (2004), dietary organic acid additions do not influence the carcass quality of fattening pigs when the dietary protein supply is adequate. So far, only Øverland et al. (2000) have reported increased carcass leanness with formate-supplemented diets. 
Vol. 15 (2006): 324-339.

Table 6. Carcass quality of growing-finishing pigs fed diets supplemented with avilamycin or increasing levels of a sorbate-coated formic acid or a blend of formic and lactic acids.

\begin{tabular}{|c|c|c|c|c|c|c|c|c|c|}
\hline \multirow[b]{2}{*}{ Acidifier addition, $\mathrm{g} \mathrm{kg}^{-1}$ of feed } & \multirow[t]{2}{*}{ Control } & \multirow[t]{2}{*}{$\begin{array}{l}\text { Avila- } \\
\text { mycin }\end{array}$} & \multicolumn{3}{|c|}{$\begin{array}{c}\text { Sorbate-coated formic } \\
\text { acid }\end{array}$} & \multicolumn{3}{|c|}{$\begin{array}{l}\text { Formic and lactic acid } \\
\text { blend }\end{array}$} & \multirow[b]{2}{*}{ SEM } \\
\hline & & & 3 & 6 & 12 & 3 & 6 & 12 & \\
\hline Carcass weight, $\mathrm{kg}$ & 77.8 & 78.5 & 78.0 & 77.3 & 78.6 & 78.0 & 78.3 & 78.3 & 0.54 \\
\hline Slaughter loss, \% & 25.7 & 25.8 & 25.8 & 26.3 & 25.6 & 26.0 & 25.7 & 25.3 & 0.32 \\
\hline Carcass gain, $\mathrm{g} \mathrm{d}^{-1}$ & 645 & 675 & 679 & $682^{\S}$ & $686^{\S}$ & $687^{\S}$ & 678 & $689^{\S}$ & 12.6 \\
\hline $\mathrm{Kg}$ dry matter per $\mathrm{kg}$ of carcass gain & 3.71 & 3.64 & 3.58 & 3.64 & $3.43^{\S \rrbracket}$ & $3.53^{\S}$ & $3.53^{\S}$ & $3.51^{\S}$ & 0.056 \\
\hline Carcass lean, $\%$ & 58.4 & 58.4 & 57.8 & 58.3 & 58.2 & 58.2 & 58.2 & 58.7 & 0.37 \\
\hline \multicolumn{10}{|l|}{ Fat thickness, $\mathrm{mm}^{\mathrm{a}}$} \\
\hline S1 & 12.1 & 12.3 & 12.6 & 12.1 & 12.2 & 12.5 & 12.2 & 12.2 & 0.33 \\
\hline $\mathrm{S} 2$ & 12.9 & 13.1 & 13.7 & 12.9 & 13.1 & 13.1 & 13.2 & 13.0 & 0.43 \\
\hline \multicolumn{10}{|l|}{ Meat colour ${ }^{\mathrm{a}, \mathrm{b}}$} \\
\hline PSE1 & 36.9 & 36.5 & 38.0 & 37.4 & 36.6 & 37.4 & 36.3 & 35.9 & 0.84 \\
\hline PSE2 & 37.2 & 36.7 & 38.0 & 36.1 & 36.4 & 36.9 & 36.7 & 36.1 & 0.69 \\
\hline
\end{tabular}

${ }^{a}$ The measurements were taken with a Hennessy GP4 grading probe, S1 and PSE1 after the last rib, $8 \mathrm{~cm}$ from the midline, and S2 and PSE2 between the 12th and 13th rib, $6 \mathrm{~cm}$ from the midline.

${ }^{\mathrm{b}}$ Meat colour is normal when the colour values are $\leq 58$, whereas values above 58 indicate pale, soft and exudative (PSE) meat.

$\S$ Significantly different from the control treatment according to the Dunnett test $(\mathrm{P}<0.05)$.

"Significantly different from the avilamycin treatment according to the Dunnett test $(\mathrm{P}<0.05)$.

\section{Stomach alterations}

The observed gastric lesions found in the pars oesophageal region of the stomach are presented in Table 7. Stomachs were collected from the slaughterhouse when a large number of pigs (at least ten) were slaughtered at the same time. Therefore, the number of pigs per treatment varied somewhat. From the 206 investigated stomachs, 109 were from gilts and 97 from barrows. The frequency of stomachs that had a normal pars oesophageal region was 39 and $25 \%$ in the negative and positive control treatments, and it ranged from 19 to $35 \%$ in the acidifier treatments. The frequency of secondand third-grade lesions, which were considered to be associated with a sensation of pain and to have an effect on the welfare of the pig (Hautala and Rautiainen 1991), tended $(\mathrm{P}=0.07)$ to be smaller in the treatment with $12 \mathrm{~g} \mathrm{~kg}^{-1}$ of the sorbatecoated formic acid than in the control. No other additive treatment differed from the negative control $(\mathrm{P}>0.05)$. So far, previous studies have not found any increase in the frequency of gastric ulcers in fattening pigs fed diets supplemented with organic acid (Øverland et al. 2000, Partanen et al. 2002, Royer and Granier 2004, Canibe et al. 2005).

In pigs, ulcers generally develop in the par oesophageal area of the stomach, whereas ulcers of the glandular area are rare (Doster 2000). Changes seen in the pars oesophageal region vary greatly. In the early stages, the pars oesophageal area becomes keratinised and roughened (Hautala and Rautiainen 1991). When the alteration advances, the surface becomes gradually eroded until an ulcer develops (Doster 2000). In this study, keratinisation was seen in 46-64\% of the stomachs in different dietary treatments. In several stomachs with second- or third-grade lesions, keratinisation was seen on the edges of the pars oesophageal area. When an ulcer heals, it leads to scarring or, in the worst cases, to strictures. The stenosis of the oesophageal opening feels like a rigid ring, and the opening can become so small that pigs often vomit after eating. Both scars and stenosis were found in 


\section{Partanen, K. et al. Growth-promoting effects of two dietary acidifiers}

Table 7. The presence of alterations in the pars oesophageal region of the stomach in growing-finishing pigs fed diets supplemented with avilamycin or increasing levels of a sorbate-coated formic acid or a blend of formic and lactic acids.

\begin{tabular}{|c|c|c|c|c|c|c|c|c|}
\hline \multirow[b]{2}{*}{ Acidifier addition, $\mathrm{g} \mathrm{kg}^{-1}$ of feed } & \multirow[t]{2}{*}{ Control } & \multirow[t]{2}{*}{$\begin{array}{l}\text { Avila- } \\
\text { mycin }\end{array}$} & \multicolumn{3}{|c|}{$\begin{array}{l}\text { Sorbate-coated } \\
\text { formic acid }\end{array}$} & \multicolumn{3}{|c|}{$\begin{array}{l}\text { Formic and lactic } \\
\text { acid blend }\end{array}$} \\
\hline & & & 3 & 6 & 12 & 3 & 6 & 12 \\
\hline Total number of investigated stomachs & 23 & 28 & 27 & 22 & 30 & 28 & 22 & 26 \\
\hline \multicolumn{9}{|l|}{ Frequencies of alterations } \\
\hline Keratinised & 0.52 & 0.46 & 0.56 & 0.64 & 0.60 & 0.64 & 0.59 & 0.58 \\
\hline Streaky grooves or tiny erosions & 0.48 & 0.39 & 0.59 & 0.45 & 0.47 & 0.54 & 0.41 & 0.35 \\
\hline Erosion down to the muscular layer & 0.22 & 0.07 & 0.15 & 0.09 & 0.03 & 0.14 & 0.00 & 0.04 \\
\hline Scarring & 0.00 & 0.11 & 0.19 & 0.14 & 0.10 & 0.00 & 0.09 & 0.12 \\
\hline Stenosis of the oesophageal opening & 0.00 & 0.07 & 0.15 & 0.05 & 0.03 & 0.00 & 0.09 & 0.11 \\
\hline Eroded, scarred or stenosis & 0.22 & 0.18 & 0.22 & 0.18 & 0.13 & 0.14 & 0.09 & 0.15 \\
\hline \multicolumn{9}{|l|}{ Frequencies of gastric lesion scores } \\
\hline Grade 0 & 0.39 & 0.25 & 0.19 & 0.27 & 0.33 & 0.29 & 0.32 & 0.35 \\
\hline Grade 1 & 0.39 & 0.64 & 0.59 & 0.64 & 0.63 & 0.61 & 0.59 & 0.54 \\
\hline Grade 2 & 0.17 & 0.11 & 0.22 & 0.05 & 0.03 & 0.11 & 0.09 & 0.08 \\
\hline Grade 3 & 0.04 & 0.00 & 0.00 & 0.05 & 0.00 & 0.00 & 0.00 & 0.04 \\
\hline $\begin{array}{l}\text { Frequency of alterations that influence the } \\
\text { welfare of the pigs }{ }^{\mathrm{a}}\end{array}$ & 0.22 & 0.11 & 0.22 & 0.09 & $0.03^{\text {II }}$ & 0.11 & 0.09 & 0.12 \\
\hline
\end{tabular}

${ }^{a}$ Grade 2 and 3 alterations (eroded or ulcerated) and stenosis of the oesophageal opening.

"A tendency for a difference to the control treatment $(\mathrm{P}=0.07)$.

the pigs of this study, which means that eroded and/or ulcerated pars oesophagi had healed. The frequency of alterations that were caused by erosion of the pars oesophageal region down to the muscular layer in some stage of the pigs' life as indicated by scarring or stenosis did not differ between dietary treatments $(\mathrm{P}>0.05)$.

At present, the cause of gastric ulcers is unknown. Fine grinding of cereals, particularly of wheat, and pelleting have been shown to be associated with the development of gastric ulcers (Regina et al. 1999, Robertson et al. 2002). The main factor causing ulceration is the mixing of proximal and distal stomach contents, resulting in more fluid and acidic digesta in the proximal stomach (Regina et al. 1999, Doster 2000, Royer and Granier 2004). According to Regina et al. (1999), the amounts of lactic and acetic acids in the stomach contents in- crease when pigs are fed coarsely instead of finely ground feed, and it is unlikely that organic acids cause ulcers. However, the increased amount of ammonia in the stomach may play a role in ulcer development (Regina et al. 1999). Dietary formic acid additions have been reported to decrease ammonia concentration in the stomach contents of pigs (Roth et al. 1992). In pigs, the role of stress and microbes in the development of gastric ulcers are still unclear (Eisemann and Argenzio 1999, Doster 2000). In this study, most of the pigs with severe stomach alterations had some health issues which could have caused stress to them, i.e. illness, leg problems, or tail biting. In addition, 6 of the 25 pigs with severe lesions originated from three litters. There is some evidence that ulcers can develop already in weaned piglets (Doster 2000), which could explain the finding that several pigs 
Vol. 15 (2006): 324-339.

with severe gastric alterations came from the same litters.

\section{Conclusions}

The additions of a sorbate-coated formic acid or of a blend containing formic and lactic acids as the major components to grower and finisher diets at levels of 3-12 $\mathrm{g} \mathrm{kg}^{-1}$ of feed had a positive effect on the performance of fattening pigs, but they did not influence the carcass quality of the pigs or the presence of gastric alterations compared to the values in the negative and positive control diets. These acidifiers enhanced the performance of fattening pigs at dietary levels that are smaller than those generally recommended for single organic acid or organic salt. This should encourage to further development of dietary acidifiers and increase the interest to use of them in fattening pig diets.

\section{References}

Association of Official Analytical Chemists 1990. Official methods of analysis. AOAC, Arlington, VA. 1298 p.

Baustad, B. 1993. Effects of formic acid on performance in growing pigs. Norwegian Journal of Agricultural Sciences 7: 61-69.

Biehl, L.G., Mansfield, M.E., Smith, A.R., Woods, G.T. \& Meyer, R.C. 1985. Health and performance of commingled feeder pigs as affected by lincomycin and carbadox. Preventive Veterinary Medicine 3: 489-497.

Bolduan, G., Beck, M. \& Schubert, C. 1991. Influence of adsorbent feed additives on weaned pigs. Tierzucht 45: 523-524.

Canibe, N., Højberg, O., Højsgaard, S. \& Jensen, B.B. 2005. Feed physical form and formic acid addition to the feed affect the gastrointestinal ecology and growth performance of growing pigs. Journal of Animal Science 83: 1287-1302.

Doster, A.R. 2000. Porcine gastric ulcer. Diagnosis of Disease of the Digestive Tract 16: 163-174.

EC 1998. Commission Directive 98/64/EC of 3 September 1998 establishing Community methods of analysis for the determination of amino acids, crude oils and fats, and olaquindox in feeding stuffs and amending Directive 71/393/EEC. Official Journal of European Commission L257: 14-28.
Eisemann, J.H. \& Argenzio, R.A. 1999. Effects of diet and housing density on growth and stomach morphology in pigs. Journal of Animal Science 77: 2709-2714.

Ferguson, N.S., Lavers, G. \& Gous, R.M. 2001. The effect of stocking density on the response of growing pigs to dietary lysine. Animal Science 72: 459-469.

Franco, L.D., Fondevila, M., Lobera, M.B. \& Castrillo, C. 2005. Effect of combinations of organic acids in weaned pig diets on microbial species of digestive tract contents and their response on digestibility. Journal of Animal Physiology and Animal Nutrition 89: 88-93.

Giger-Reverdin, S., Duvaux-Ponter, C., Sauvant, D., Martin, O., Nunes do Prado, I. \& Müller, R. 2002. Intrinsic buffering capacity of feedstuffs. Animal Feed Science and Technology 96: 83-102.

Hautala, M. \& Rautiainen, E. 1991. A comparative study of feeder pig units using dry liquid feeding in the western part of Finland. Part 2: Assessment and categorization of the gastric lesions in pigs. Finnish Veterinary Journal 97: 298-307.

Jensen, B.B. 1998. The impact of feed additives on the microbial ecology of the gut in young pigs. Journal of Animal and Feed Sciences 7: 45-64.

Jongbloed, A.W., Mroz, Z., van der Weij-Jongbloed, R. \& Kemme, P.A. 2000. The effects of microbial phytase, organic acids and their interaction in diets for growing pigs. Livestock Production Science 67: 113-122.

Jørgensen, L. \& Boes, J. 2004. Benzoesyre og mælke-/myresyre til smågrise. Landsudvalget for Svin. Faglig publication, Meddelelse nr. 677. 10 p. Cited 8 March 2005. Updated 9 November 2004. Available on the Internet: http://www.lu.dk/index.aspx?id=45ae1f6f-14c3-48d48595-e0c7f4711343

Kirchgessner, M., Paulicks, B.R. \& Roth, F.X. 1997. Effects of supplementations of diformate complexes (Formi ${ }^{\mathrm{TM}}$ LHS) on growth and carcass performance of piglets and fattening pigs in response to application time. Agribiological Research 50: 1-10.

Kirchgessner, M., Roth, F.X. \& Paulicks, B.R. 1995. Nutritive efficacy of sorbic acid in the rearing of piglets. Journal of Animal Physiology and Animal Nutrition 74: 235242.

Korunic, Z. 1998. Diatomaceous earths, a group of natural insecticides. Journal of Stored Products Research 34: 87-97.

Lindermayer, H. \& Propstmeier, G. 1994. Growth promoters throughout fattening? Kraftfutter 12: 479-481, 488.

Maribo, H. 1999. Firmaprodukter til smågrise - mælkesyre, Lafeed 80. Landsudvalget for Svin. Faglig Publication, Meddelelse nr. 428. 6 p. Cited 15 February 2006. Updated 12 May 1999. Available on the Internet: http:// www.lu.dk/index.aspx?id=e325f4ca-22b9-48df-81ee$27386 \mathrm{c} 516 \mathrm{cda}$

Maribo, H., Jensen, B.B. \& Hedemann, M.S. 2000a. Forskellige doseringer af organiske syrer til smågrise. Landsudvalget for Svin. Faglig Publication, Meddelelse nr. 469. Danske Slakterier. $21 \mathrm{p}$.

Maribo, H., Mikkelsen, L.L. \& Jensen, B.B. 2004. Firmaprodukter til smågrise: Produkter indeholdende organiske syrer - $\mathrm{CH} 01-141 \mathrm{i}$ tre doseringer og $\mathrm{CH} 01-186 \mathrm{i}$ en dosering. Landsudvalget for Svin. Faglig Publication nr. 666. 12 p. Cited 6 February 2006. Updated 26 July 
Partanen, K. et al. Growth-promoting effects of two dietary acidifiers

2004. Available on the Internet: http://www.lu.dk/index. aspx?id=e500695c-55da-4fd8-a03d-f6b980287621

Maribo, H., Olsen, L.E., Jensen, B.B. \& Miquel, N. $2000 \mathrm{~b}$. Produkter til smågrise: kombinationen af mælkesyre og myresyre og benzoesyre. Landsudvalget for Svin, Faklig Publication nr. 490. 16 p. Cited 8 March 2005. Updated 23 November 2000. Available on the Internet: http://www.lu.dk/index.aspx?id=47e22c9c-b401-4ce1$838 \mathrm{e}-115 \mathrm{dd} 8 \mathrm{~d} 62700$

Matsuda, T., Yano, T., Maruyama, A. \& Kumagai, H. 1994. Antimicrobial activities of organic acids determined by minimal inhibitory concentrations at different $\mathrm{pH}$ ranged from 4.0 to 7.0. Nippon Shokuhin Kogyo Gakkaishi 41: $687-702$.

Øverland, M., Granli, T., Kjos, N.P., Fjetland, O., Steien, S.H. \& Stokstad, M. 2000. Effect of dietary formates on growth performance, carcass traits, sensory quality, intestinal microflora, and stomach alterations in growingfinishing pigs. Journal of Animal Science 78: 18751884.

Partanen, K., Jalava, T., Valaja, J., Perttilä, S., SiljanderRasi, H. \& Lindeberg, H. 2001. Effect of dietary carbadox or formic acid and fibre level on ileal and faecal nutrient digestibility and microbial metabolite concentrations in ileal digesta of the pig. Animal Feed Science and Technology 93: 137-155.

Partanen, K. \& Mroz, Z. 1999. Organic acids for performance enhancement in pig diets. Nutrition Research Reviews 12: 117-145.

Partanen, K., Siljander-Rasi, H., Alaviuhkola, T., Suomi, K. \& Fossi, M. 2002. Performance of growing-finishing pigs fed medium- or high-fibre diets supplemented with avilamycin, formic acid or formic acid-sorbate blend. Livestock Production Science 73: 139-152.

Prohászka, L. \& Baron, F. 1980. The predisposing role of high dietary protein supplies in enteropathogenic $E$. coli infections of weaned pigs. Zentralblatt für Veterinärmedizin 27B: 222-232.

Regina, D.C., Eisemann,J.H., Lang, J.A. \& Argentzio, R.A. 1999. Changes in gastric contents in pigs fed a finely ground and pelleted or coarsely ground meal diet. Journal of Animal Science 77: 2721-2729.

Robertson, I.D., Accioly, J.M., Moore, K.M., Driesen, S.J.,
Pethick, D.W. \& Hampson, D.J. 2002. Risk factors for gastric ulcers in Australian pigs at slaughter. Preventive Veterinary Medicine 53: 293-303.

Roth, F.X., Eckel, B., Kirchgessner, M. \& Eidelsburger, U. 1992. Influence of formic acid on $\mathrm{pH}$-value, dry matter content, concentrations of volatile fatty acids and lactic acid in the gastrointestinal tract. 3. Investigations about the nutritive efficacy of organic acids in the rearing of piglets. Journal of Animal Physiology and Animal Nutrition 67: 148-156.

Roth, F.X., Kirchgessner, M. \& Eidelsburger, U. 1993. Nutritive efficiency of lactic acid in the rearing of piglets. Agribiological Research 46: 229-239.

Roth, F.X. \& Raczek, N.N. 2003. Nutritive effectiveness of sorbic acid: effects in piglet feeding. Kraftfutter 86 : 105110.

Royer, E. \& Granier, R. 2004. Effects of acidification of the diet on carcass traits and gastric ulcers. Techni Porc 27, 6: 7-15.

Schiemann, R., Nehring, K., Hoffmann, L., Jentsch, W. \& Chudy, A. 1972. Energetische Futterbewertung und Energienormen. Berlin: VEB Deutscher Landwirtschaftsverlag. 344 p.

Sigfridson, K. \& Göransson, L. 2003. FA2300S och Ca-formiat $i$ foder till slaktsvin. Rapport, Svenska Lantmännen, Sveriges SvinCenter, Svalöv. $17 \mathrm{p}$.

Siljander-Rasi, H., Alaviuhkola, T. \& Suomi, K. 1998. Carbadox, formic acid and potato fibre as feed additives for growing pigs. Journal of Animal and Feed Sciences 7, Supp 1: 205-209.

Snedecor, G.W. \& Cochran, W.G. 1989. Statistical methods. Ames: lowa State University Press. 8. Edition, 503 p.

Sofos, J.N. \& Busta, F.F. 1993. Sorbic acid and sorbates. In: Davidson, P.M. \& Branen, A.L. (eds.). Antimicrobials in foods. New York: Marcel Dekker, Inc. p. 49-94.

Tuori, M., Kaustell, K., Valaja, J., Aimonen, E., Saarisalo, E. \& Huhtanen, P. 1996. Rehutaulukot ja ruokintasuositukset. Helsinki: Yliopistopaino. 92 p.

Virtanen, E., Nilsson, B. \& Khajarern, J. 2004. Organic acids in pig nutrition - novel solutions. In: AFMA Forum 2004 Papers. Cited 15 March 2006. Available on the Internet: http://www.afma.co.za/AFMA_Template/feedpaper16.html 


\title{
SELOSTUS
}

\section{Sorbaatilla päällystetyn muurahaishapon ja muurahais-maitohapposeoksen vaikutukset lihasikojen tuotantotuloksiin, ruhon laatuun ja mahalaukun muutoksiin}

\author{
Kirsi Partanen, Maija Karhapää, Hilkka Siljander-Rasi, Erkki Virtanen ja Bernt Nilsson \\ Maa- ja elintarviketalouden tutkimuskeskus ja Kemira GrowHow Oy
}

Tutkimuksen tarkoituksena oli selvittää kahden muurahaishappopohjaisen happovalmisteen tehoa pieninä pitoisuuksina lihasikojen kasvun edistäjänä. Sorbaatilla päällystetty muurahaishappo sisälsi piimaahan imeytettyä muurahaishappoa ja ammoniumformiaattia, joka oli päällystetty kaliumsorbaatilla. Tässä kiinteässä happovalmisteessa oli noin $50 \%$ piimaata, ja sorbiini- ja muurahaishapon suhde oli siinä 5,2:100 100-prosenttisina happoina. Muurahais-maitohapposeos sisälsi pääasiassa muurahais- ja maitohappoa, ja tässä nestemäisessä happovalmisteessa maito- ja muurahaishapon suhde oli 28:100 100-prosenttisina happoina. Tutkimuksessa oli 320 lihasikaa, jotka kasvatettiin noin $21 \mathrm{~kg}$ painosta noin $105 \mathrm{~kg}$ painoon. Molempia happovalmisteita lisättiin lihasikojen alku- ja loppukasvatusrehuihin 3, 6 tai 12 $\mathrm{g} / \mathrm{kg}$. Negatiivisena kontrollina oli lisäaineeton ruokinta ja positiivisena kontrollina ruokinta, jossa alkukasvatusrehuun lisättiin avilamysiini-antibioottia $40 \mathrm{mg} / \mathrm{kg}$.

Kumpikaan happovalmiste ja avilamysiini eivät vaikuttaneet merkitsevästi sikojen kasvuun, eikä rehuhyötysuhteeseen alkukasvatuksen aikana. Loppukasvatuksessa sikojen kasvu parani, kun sorbaatilla päällystet- tyä muurahaishappoa lisättiin rehuun 3-12 $\mathrm{g} \mathrm{kg}^{-1}$. Rehuhyötysuhde parani, kun tätä valmistetta lisättiin 3 tai 12 $\mathrm{g} \mathrm{kg}^{-1}$. Koko kasvatusajan kasvu oli kahdella suurimmalla lisäystasolla parempi kuin negatiivisessa kontrolliryhmässä, ja suurin lisäys paransi rehuhyötysuhdetta. Pienin muurahais-maitohapposeoksen lisäys paransi sikojen kasvua loppukasvatuksessa ja koko kokeen aikana, ja kaikki lisäystasot paransivat rehuhyötysuhdetta negatiiviseen kontrolliryhmään verrattuna. Happovalmisteet eivät vaikuttaneet ruhojen teuraslaatuun. Negatiiviseen kontrolliryhmään verrattuna vakavia mahahaavaan viittaavia muutoksia havaittiin hieman vähemmän, kun rehuun lisättiin $12 \mathrm{~g} \mathrm{~kg}^{-1}$ sorbaatilla päällystettyä muurahaishappoa. Muissa happolisäysryhmissä havaittujen mahalaukun muutosten määrä ei eronnut negatiivisesta kontrolliryhmästä. Tulosten perusteella kiinteä, kantajaaineeseen imeytetty ja sorbaatilla päällystetty muurahaishappo ja muurahais-maitohapposeos edistävät lihasikojen kasvua ja parantavat rehuhyötysuhdetta jo pieninä lisäysmäärinä, mutta nämä happovalmisteet eivät vaikuta ruhon teuraslaatuun, eivätkä aiheuta mahahaavaan johtavia muutoksia sian mahalaukussa. 